\title{
Connecting the ancient and the modern Middle East in museums and public space
}

\author{
Mirjam Brusius
}

Due to nineteenth-century austerity measures, the Fourth Plinth on Trafalgar Square, one of the most significant squares in London, never got the planned equestrian statue of royal or military figures of significance. Instead, it had to wait empty until 1999, when it became a prominent site of display for contemporary art, providing an ever-changing and free exhibition space for pedestrians passing by to evoke their own personal stories. ${ }^{1}$

In spring 2018, a recreation of an ancient winged bull statue, reportedly destroyed by ISIS in Iraq in 2015, was unveiled as the penultimate installation to perch atop the Fourth Plinth. The artwork by Iraqi-American artist Michael Rakowitz, constructed from 10,500 empty date syrup tin cans, resembled the original ancient sculpture of a lamassu, a mythological winged bull creature with the head of a man that once stood guard over the royal palace of King Ashurnasirpal II (883-859 BC) in the city of Nimroud, ancient Mesopotamia, today's Iraq, for over a 1,000 years.

To see these original ancient sculptures, people in Europe do not have to travel far. For more than a century, archaeologists and philologists have been able to admire and study them in the major museums of London, Paris and Berlin. In London's British Museum, for example, they have been on display since around 1850, after British forces had excavated them in Mesopotamia from the 1840s onwards. In Victorian Britain, the region was marked as part of the Victorians' own history; the 'cradle of civilization', supposedly rediscovered by the British. The artefacts they found, including the famous winged bulls and lions, were meant to become material witnesses known from the Old Testament. They made the Bible tangible and 'historical', an aspect that was enforced by thousands of cuneiform tablets that had yet to be deciphered (Bohrer, 2003). They were, for example, believed to contain Biblical places and names of people, besides giving insight into ancient scientific and mathematical knowledge (Robson, 2008; Robson, 2019). This context as well as the fact that the objects themselves had to be studied, measured, contextualised, taxonomised and deciphered in order to be interpreted according to Western scholarly standards, turned them into 'epistemic' objects, yielding knowledge from ancient times. In many non-Western museum collections, these taxonomies and conceptions of ancient artefacts have remained largely unchallenged since the nineteenth century. These displays, merely focussing on ancient objects and archaeology as an expert 'scholarly field', however, had often 


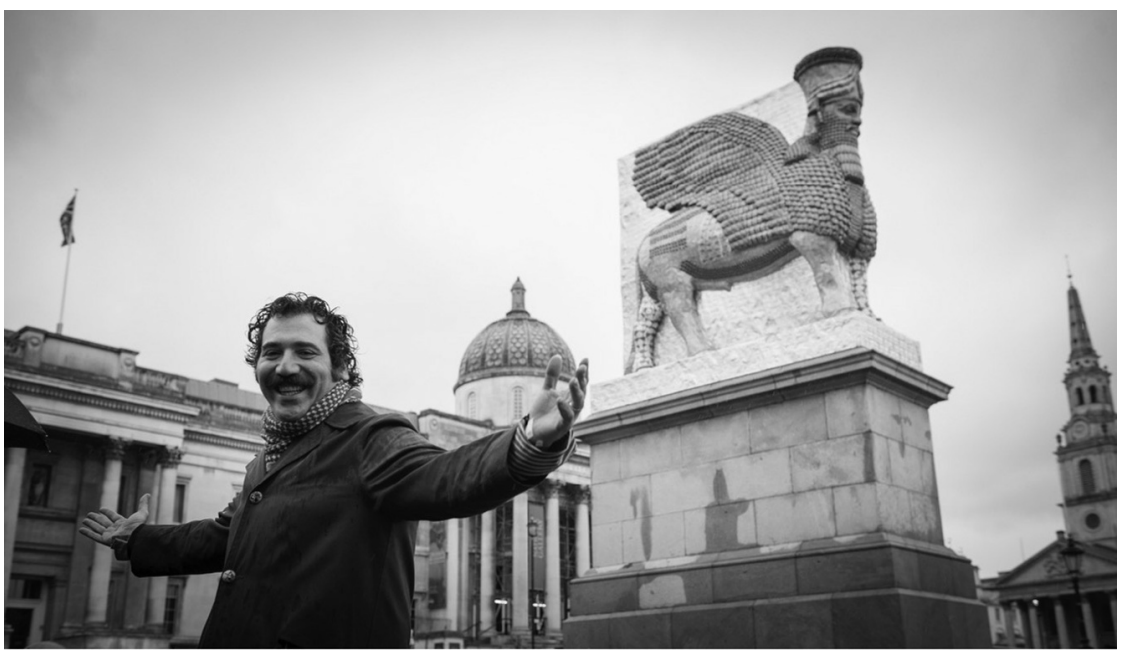

Figure 9.I Michael Rakowitz in front of The Invisible Enemy Should Not Exist in Trafalgar Square. Photograph by Caroline Teo.

omitted their 'afterlife', that is, the social and religious function of objects throughout history subsequent to their making until today.

Rakowitz's artwork did not evoke scholarly or biblical knowledge, fascination or even sensation and curiosity. Neither was his statue built to last. It even undermined the preservationist ideas that its counterparts in the museum so strictly adhere to. Objects in the museum are meant to be preserved for the unforeseen future, if not on site in Iraq, in an exhibition hall or the museum's storage area, notwithstanding the fact that some of the stored objects might never be seen. Instead, his artwork was dedicated to a specific configuration of ancient objects from Mesopotamia in society, involving not just art experts, scholars and exhibition professionals, but also politicians, the media, and the wider public.

As an example of how fluid the meaning of such artefacts can be, it was, above all, not a replica but a 'revival' of the sculpture that it intended to evoke. Rakowitz, whose Arab-Jewish family had to leave Iraq in 1946 for the United States where he was born, provoked some pressing questions: Should heritage be preserved, replaced and reproduced, for example, at a time when war and violence make other matters more urgent? His work answered the question by showing that art can instead create something new, evoking the loss and absence of humans. As a placeholder for something else, 'reborn' from ordinary objects of everyday life, the sculpture was, as the artist described it 'a palimpsest of loss' (Kennedy, 2018) for the people of Iraq, their cultural history, and a once great export industry.

When media and the public responded to Rakowitz's sculpture, war and the current destruction of archaeological sites in Iraq were obvious reference points. Only few mentioned the 'real' sculptures that 'lived' not only in Iraq but in fact peacefully only a few miles away in the British Museum, and other Western museum collections. In fact, it was in the British Museum, where Rakowitz 
initially saw these sculptures as a 10 -year-old boy. Yet the kind of context we find in such museums could not be more different since the present-day realities of the place whence the objects once came rarely play any role. Museum visitors sometimes even struggle to realise that 'ancient Mesopotamia' still 'exists' in as much as it lives on in modern countries such as Iraq. This is because museums have disconnected and still largely disconnect these kinds of sculptures from a range of 'alternative narratives': those that connect them with more recent histories of violence and war; those that acknowledge the role of these artefacts as 'signifiers' from the 'Islamicate World' both for the modern societies in this region and for Europe's large Muslim diasporas, as well as those that embed them into the long history of Western imperialism and expansion in the Middle East. Indeed, as museum critique and writer Sumaya Kassim reminds us in the context of a recent British Museum exhibition on orientalism, what most museums call the 'cradle of civilization' has in fact been a war zone for a long time:

I am standing in what I am told is the centre of civilisation, and yet all I see are flames. For many of us, the past few decades have been nightmarish. In the past few weeks alone, Muslims have been rendered stateless, put into concentration camps, the most powerful man in the world threatened to bomb Iranian cultural sites, air strikes on Mogadishu, Yemen, Iraq... Enclosed in this intricate, delicate space one might not think of the fire that has been burning and burning for centuries. And I, seeing this, recognise that Britishness is characterised only by its harrowing disconnect from reality. Nowhere is this more profoundly experienced than in the British Museum. What would an exhibition look like if it took seriously the desire for self-determination? What would an exhibition look like if it accepted our agency and the political consequences of that agency? What would happen if an exhibition showed how the British purposefully and brutally extinguished the hopes of their colonial subjects? What would it have looked like for a public space, like a national museum, to have cared and provided space for us?

(Kassim, 2020)

Could a museum display of Middle Eastern artefacts evoke reactions similar to those evoked by Rakowitz's artwork? What prevents museums from connecting the ancient and the modern inside the museum walls, just as Rakowitz managed to achieve in a public square? The aim here is not to engage in finger-pointing, or to provide a solution. Those who have worked in museums are familiar with institutional obstacles and difficulties when it comes to changing permanent displays. Instead, I would like to reflect on how a future narrative breaking from the legacy of colonial discourses could be envisioned, hereby initiating a dialogue between historians and museum practitioners.

\section{The Middle East in the museum}

Since the nineteenth century, museums in Europe and 'the West' have displayed Mesopotamian objects as part of their 'own' history. These canonical ideas, shaped 
by Western European readings, have influenced museological and public notions of progress and decline, the organization of historical time, but also scholarly disciplines. They did so by means of key concepts in history of science, such as 'origin' and 'discovery', which account for a single and teleological narrative rather than for dynamic flows of exchange between spaces.

In museums, the Mesopotamian artefacts that I will focus on here, for example, are not only geographically but also epistemically dislocated and detached from the region where they were once excavated:Ancient Mesopotamia, for example, occupied the same space as much of modern-day Iraq, Syria and Iran. In Western museums, however, artefacts from Mesopotamia are often presented in direct proximity to objects deeply embedded in the Western canon, such as Classical Greek sculpture. Objects from the same region that derive from after the coming of Islam are often separated from their more ancient geographical counterparts, and displayed in other areas of the museum, including Islamic Art departments. This dislodges them from narratives that museums developed around the category of 'Islamic Art'. In other words, the authoritative voice of the museum orders geographies and temporalities, hereby establishing distances and proximities through its display (Shatanawi, this volume).

The epistemological implications this narrative has for the perception of history has been denounced, for instance, by Zainab Bahrani (1998). Prevailing European narratives link their historical present to mythical beginnings in the Middle East via the notions of a classical Graeco-Roman Antiquity. They identify Egypt and ancient Mesopotamia as the 'cradle of Western civilizations'. These 'lost civilizations' were incorporated into European narratives and identity, subsequently and supposedly 'discovered' by European archaeologists and explorers. The designated taxonomy of Ancient Near Eastern Art as 'European' creates a problematic vision of the Middle East, suggesting a period of decline from the seventh century AD onwards. What counts as canonical in Western traditions and what is subject to alienation is thus a temporal rather than geographical dichotomy.

As museum visitors make their ways to the 'Islamic' department, however, they will often find the exact opposite; that is, a display not centring on decline from the seventh century AD onwards, but on the idea of a flourishing Middle East. Here, the categories of 'Islamic Art' (Shalem, 2012; Shaw, 2019; Karaca, this volume) alongside 'Islamic Science' are generally used to refer to the medieval 'Golden Age', during which the Muslim world is considered to have made important contributions to natural philosophy, medicine and mathematics. The category of Islamic science was created in 1976 for a London exhibition to offer a sense of inclusiveness for a particular British public (mainly Asian-born and of Muslim origin, such as the large Western Kashmiri population; Harrow \& Wilson, 1976; Al-Khalili, 2010).

Even if created to help build the self-esteem of a particular community, however, displays foregrounding Islam often run the risk of presenting an alternative orientalist trope - one of the flourishing medieval centre of the scientific world in an otherwise 'eternal, unchanging East' deprived of modernity. Further, 'Islamic instruments', such as astrolabes from the 'Islamicate world', one could argue, are neither solely scientific instruments, nor dependent on religious categories. They also come from a 
wide-ranging geographical area. As living objects, they were subject to circulation and continuous interaction. The imbued meanings that derive from such interaction are as manifold as the multiple audiences that encounter them in museums. What had turned these objects into 'Islamic Science' in the first place? In how far is the 'history of science' as a discipline of history building and canonising complicit as a resource for building such narratives? While both labels, 'Ancient Near Eastern' and 'Islamic' are both problematic, the former (unlike the latter) has long been unchallenged in museum practice. Like many museum categories, it has become invisible as a constructed category that warrants critical analysis in its own right.

In recent years, however, several curators have become aware of the one-dimensional nature of most current displays (Emberling \& Petit, 2019; Gansell \& Shafer, 2019). ${ }^{2}$ The ongoing restructuring of some museum spaces, including planned changes of galleries displaying Egyptian and Mesopotamian artefacts in institutions such as British Museum and the Pergamonmuseum, reflects discomfort with this status quo, although not always in favour of a more even and unifying approach. In museums, the 'ethnologization', that is, the 'othering' of Islam, still pushes the Middle East to the margins, while the 'religionisation' of the Middle East often does the same in academic contexts. Islam, as Kassim notes 'is still seen as a menacing spectre haunting the West' (Kassim, 2020). If exhibitions foreground Eurocentric narratives, including orientalist approaches, however, it implies that they are premised on an assumption that take for granted that the audience is White and 'western' (European).

The problematic categories of museum spaces are mirrored in the naming of university departments throughout the world, which tell a story of their own: How religious does the Middle East's history has to be in order to be taught in Islamic studies (Islamwissenschaft, for example, in Germany)? How 'oriental' is the Middle East to be approached as part of 'Oriental studies'? How ancient does the Near East have to be in order to be 'Near'? And how ancient Western Asia in order to be 'western'? How modern the Middle East in order to be in the 'Middle'? And how much in the middle does the East have to be in order to be 'modern'? All these questions are important, albeit somewhat cumbersome, routes to provoke the following discussion: How can museum display today respond to these disciplinary discourses; and how can it make ancient Near Eastern artefacts relevant for people in and from the modern Middle East?

Lastly, besides more specialised academic and museological discourses, there is also a broader public media debate (Brusius, 2016; Brusius, 2017a). In particular, in recent years, when conflict and violence dominated the news about the region, discussions on heritage and its destruction in the Middle East became monolithic. Most media often equated 'the Orient' with destruction and 'the West' with salvage. As pointed out by a number of scholars, however, these tropes are deeply problematic (Bernbeck, 2013; Bohrer, 2015; Riggs, 2011). They still replicate nineteenth- and twentieth-century stances of imperialism - a context in which many museum collections have their origins. Archaeology as a mediating discipline connecting the present with the past was particularly fundamental in creating and undergirding museological taxonomies. Even though many have critiqued the 
legacies of formerly colonial structures in recent decades, the vital role archaeology played in European imperial expansion in the Middle East must still be fully explored (Díaz-Andreu, 2007; Meskell, 1998; Pollock \& Bernbeck, 2005). In museum displays, this role is mostly absent. Colonial histories would provide the missing links between the appropriated 'Ancient Near East' and the 'othered' nineteenth-century Middle East (then largely consisting of the Ottoman Empire). For it was during the height of colonial expansion in the nineteenth century that both alienating 'images' of the region were constructed. Visitors must learn how and why these categories came into being.

\section{Ghosts}

Rakowitz sculpture has been described as "the life-sized "ghost" of the Assyrian originals (Armitstead, 2018). The artist himself used the expression to describe it as something capable of more than a placeholder or a model:

The salvage of date syrup cans in this work makes present the human, economic and ecological disasters caused by the Iraq wars and their aftermath. [...] The reconstruction of the lamassu set on the Fourth Plinth allows an apparition to haunt Trafalgar Square at a time when we are witnessing a massive migration of people fleeing Iraq and Syria. I see this work as a ghost of the original and as a placeholder for those human lives that cannot be reconstructed, that are still searching for sanctuary.

(Rakowitz cited in Luke, 2018)

Public reactions echoed these humanist intentions: 'Here is my country, for real here in the middle of this city, for so many people to see - wonderful, but I have tears also', a Londoner of Iraqi descendent wrote (Kennedy, 2018). Another passer-by praised the cultural complexity behind the installation on social media: 'An Assyrian winged bull made out of Iraqi date syrup cans by a Jewish artist unveiled by a Muslim mayor. I BLOODY LOVE LONDON!' (Shamouel, 30.3.2018). A number of aspects set a new tone for the display, and the reactions it provoked. They differed considerably from the canonised and museological context in which audiences in London would have encountered Mesopotamian artefacts otherwise, for example in the British Museum: the unorthodox material the artist used to recreate the sculpture; the pop-up kiosk across the square, selling small books of recipes, cakes and treats involving date syrup (Searle, 2018); the connection to the artist's family history, as they had to flee Iraq in $1946 ;^{3}$ but also the very fact that it could be seen by a diverse range of audiences on Trafalgar Square without the social 'pressures' that museums tend to bring along by catering mainly to the White middle class (Sherman, 2008). London's mayor Sadiq Khan even claimed its prominent display in a place where millions of people could see it might make it 'the world's most high-profile piece of art' (Kennedy, 2018).

Yet with the highly politicised space also came political patronage and a moral message. Khan described the sculpture 'as an act of resilience against tyranny and 
religious fanaticism, and a celebration of pluralism' (ibid.). Others praised the connection the sculpture made with the artist's home country and Britain's involvement in its politics, grounding these arguments on more specific observations. The British daily 'The Guardian' noted, for example, that the sculpture turned 'its back to the National Gallery, gazing south-east past the Foreign Office and the Houses of Parliament towards its spiritual home in the Middle East'. It thus turned its gaze towards Nineveh, past the place where the 2003 British invasion of Iraq was decided. This gaze can be considered a human reference to conflict, not simply a nostalgic one to a past, or a 'heritage', that no longer exists. Of course, these questions referenced the context of enunciation surrounding the sculpture. Can its official endorsement by public authorities of a country that attacked Iraq (the political party of the then Mayor of London actively supported the Iraq war) neutralise its critical message? And does this recent history influence the forms and content of its mises en scène?

\section{A political stage for display}

Rakowitz's open-air exhibition was not the first event that displayed an object reminiscent of Middle Eastern heritage on Trafalgar Square. When, in February 2015, a footage emerged of the destruction of artefacts in Iraq and Syria, heritage organisations and policy-makers were quick to discuss how these physical gaps left by those who destroyed Middle Eastern sites could be filled. They too used public display as a means to make a political point. High profile politicians took sides, such as London's then mayor Boris Johnson who materialised his position in the debate with the help of a replica of Palmyra's destroyed arch, which he - just like his successor Sadiq Khan several years later - personally unveiled in London's Trafalgar Square. Palmyra, an oasis in the Syrian desert, north-east of Damascus, a UNESCO heritage site with monumental ruins of one of the most important cultural centres of the ancient world, had come under attack in the Syrian war. Digitally developed in Oxford, materially manufactured in Italy from Egyptian marble, and set up in the centre of London (and subsequently in New York and Dubai), the arch was a sumptuous statement of cultural authority.

What made the already disputed undertaking further problematic, was - in contrast to Rakowitz's artwork - not only the high costs associated with it, but also the imperial setting in which it was first presented. The replica arch was exposed right in between Nelson's Column and the National Gallery, a museum that, like many others, stands for the idea that this is where heritage should be persevered. Even more so if it is under threat elsewhere. Yet lacking the ability to speak to various audiences in a metropolis with a large Muslim and Middle Eastern diaspora at a time when Islamophobia continued to be on the rise, this heritage was not presented as 'their heritage'. While Rakowitz's work resisted the topographical challenges and wider implications (under a new Labour Mayor of London), the replica arch and the rhetoric that surrounded it did not. Instead, Johnson saw it as an act of pride; an act against violence 'in the quest to share the experience of this irreplaceable artefact with as many people as possible' (Oliver, 
2016). Roger Michel, the director of Oxford's Institute for Digital Archaeology, who carried out the project, declared 'when history is erased in this fashion, it must be promptly and, of course, thoughtfully restored' (Brown, 2016). Others interpreted the display as an 'act of defiance' to show that restoration of the heritage site can be made possible 'if only the will is there' (Brown, 2016). The majority of the public seemed to echo those opinions, and so did many public museums in the Western world. Around the same time local and foreign specialists united to plan the resurrection of the ancient ruins in Syria with the help of photography and 3D printing (Cunliffe, 2016).

Meanwhile, the discussion surrounding Palmyra was entirely detached from human voices like the one of Syrian archaeologist and a former inhabitant of Palmyra, Salam al-Kuntar, who knew the site as a 'living site' just like Rakowitz's family knew Iraq:

I have a special love for Palmyra because the Temple of Bel is where my mother was born. My grandfather was a policeman serving in Palmyra and my grandmother wasn't even 20 years old when she got married and moved to Palmyra. The Palmyrene women taught her how to make bread and cook. I hear many stories about the building, how people used the space, how children played around, including my mum. So that's what it means to me. This is the meaning of heritage - it's not only architecture or artefacts that are representing history, it's these memories and ancestral connection to the place.

(Tharoor \& Maruf, 2016; see also Shaw, 2018)

Historians pointed out that inside the ruins a village was once located the inhabitants of which were expelled when the French authorities reconstructed Palmyra as a monumental tourist site during the Mandate period. ${ }^{4}$ Yet these insightful and moving testimonies were quickly forgotten in light of eager and scientifically informed discussions about digital reconstructions and museological safeguarding.

Needless to say that, compared to the sleek 3D-printed 2016 replica of the Palmyra arch, Rakowitz's individual take on the matter made 'for a more thoughtprovoking and powerful piece of public art' (McEwan, 2018) than a 3D arch, which compensated an event of destruction that was part of the very same violent, destructive and Western imperial discourse, without making those links in public. In turn, 'for an artist whose family escaped Iraq only to witness their new country invade their old, Rakowitz's mission is a poignant one', writes McEwan. She highlights that 'the choice for him to fill the plinth that looks down Whitehall to the site where Britain's decision to invade Iraq was broiled up seems somehow natural in the current political climate' (ibid). The sculpture thus allowed for a historical reference, from the spatial and political division of the Ottoman Empire into European mandates in the early twentieth century, to Britain's responsibilities (e.g. invasions) in these conflicts and the subsequent destruction of people and buildings today, which also included a number of important Islamic shrines. By contrast, when the 3-D arch was installed, media and statements by academic bodies or heritage organisations seemed to suggest that there was 'A Middle East', 'An antiquity' and 
'A heritage' deemed valuable collectively, and therefore in need of saving, irrespective of the fact that 'the past' was never a finite resource and the very definition of 'the past' has always been a contestable idea in the Middle East. Here, over the past 150 years, different political leaders have had entirely variable preferences about their respective material heritages, intimately tied to political and religious ideologies (Abu El-Haj, 2001; Galor, 2017). Authoritarian rulers such as Saddam Hussein in Iraq or Reza Shah in Persia, for example, identified with ancient kings like Nebuchadnezzar resp. Cyrus the Great. Finally, the debates rarely considered that preservation and destruction were never necessarily binary concepts or even opponents. Instead, they have always been potential accomplices, when objects were sometimes destroyed precisely because they were considered worthy of preservation by opposing parties. Often, attacks on 'shared heritage' are in reality targeted subversions of the very Western 'heritage paradigm' (Brusius, 2019).

So how longer can museums ignore Europe's historical responsibilities in the emergence of the very same conflicts that cause many to believe objects are 'safer' in Western museums? The fact that imperial interventions and recent wars were initiated by 'the West', or that President Trump threatened to attack cultural heritage sites in Iran in early 2020 (Trump, 2020), only highlights the many ironies at play in the current museum and heritage discourse. Albeit condemned by some high-profile Western institutions such as the Getty Institute, Western response (see e.g. Cuno, 2020) exemplified once again that unlike their Islamic heritage 'counterparts', ancient sites are considered 'shared heritage', that is, sites that seemingly belong to 'everyone'; a concept which so called 'universal museums' often adopt for their own end. Taking responsibility, and acknowledging human value and suffering, by contrast, would go beyond the simple paradigm that objects are 'saved' by the West in times of conflict in the Middle East, and must be replicated. Rakowitz brought home the point about the 'ultimate dehumanisation of the Iraqi people and its culture from 2003 onwards' and the 'tendency towards thinking that anything can be replicated as long as you 3D scan it. [But] you can't 3D print the people who lose their lives along with the cultural heritage that suffers' (Luke, 2018).

\section{Kings and oil}

The British Museum all of the sudden became a space for the many when the BP-sponsored exhibition 'I am Ashurbanipal: king of the world, king of Assyria' opened in 2018 and attracted a diverse range of visitors. But rather than marvel the spectacular finds from Mesopotamia, Iraqi Londoners and other activists gathered in the museum to sing and chant in a huge crowd outside the doorway of the exhibition. Making the link between BP, climate change, colonialism and the 2003 invasion of Iraq, these protests continued long after the show closed, and culminated in a 3-day mass event at the British Museum in February 2020. The activist Yasmin Younis (2019) described the movement with the following words:

The most formidable years of my life were filled with self-hatred and selfdoubt as the world turned against my people and 'Iraq' became synonymous 
with 'war' and 'violence'. Whenever I tried to learn about my history or my culture outside of intimate familial settings, my searches were limited to violence, war, and casualty. This is a sad reality for all Iraqis, as our culture is rich and beautiful and should be celebrated with dignity and respect. I should be able to learn about my culture without moral conflict. Iraqis in Iraq should be able to learn and celebrate their culture and history, but they can't as these artifacts were stolen from them... To BP and the British Museum, I say how DARE you use my culture and my history as an attempt to hide your colonialist skeletons. Not my culture, not my country. No war, no warming!

Demanding not only 'historical facts' but also a 'space to mourn, to meditate, to collectivise' (Kassim, 2020), calls for a more genuine engagement with the British Museum's imperial past subsequently became louder and louder. Younis explained that she looked 'forward to the day when the British Museum stops promoting a destructive oil giant and starts genuinely addressing the colonial nature of so much of its collection and its displays. Until then, this feels like a movement that is only going to keep on growing' (Younis, 2019). 'BP must fall', in other words, also meant 'decolonising the museum'. The request was founded in the conviction that the institution must also acknowledge the colonial structures on which its collection was founded. After all, the Western concept of 'heritage' and values of preservation, including the discipline of archaeology itself, emerged through colonial trajectories of fieldwork, survey and imperial expansion. As a nineteenth-century invention and imperial tool shaped by Western ideology and power, archaeology was also deeply enmeshed and inextricably linked with the oil business and economic exploitation.

The lack of critical display of colonial histories played a crucial role in these protests, and does so to this date. As of yet, most of these artefacts are rarely discussed in the context of imperial and colonial histories or modern conflict. The 'journey' and subsequent display of objects is almost never told as a history of contingencies, and one that heavily relied on local expertise. Instead, museums mostly tell a triumphalist story about their excavation and arrival, focusing on single archaeologists, and rarely on the anonymous labour behind the digs (Quirke, 2010). Albeit an abundance of archival sources gives plenty of insight into the challenging logistics involved in transporting the objects, and even their loss during their journey, we learn next to nothing about these 'difficulties' on display. While lesser-known written sources, for example, the minutes of the British Museum's trustees, hardly give the impression that the excavations had clear aims, published nineteenth-century sources held up an image of success. Until recently, research had not sufficiently distanced itself from these published primary accounts. The famous 1848 publication Nineveh and its Remains by Austen Henry Layard (18171894), who was first in charge of overseeing the excavations, narrates the expedition as if it had a clear purpose, emphasising the successful integration of the finds into European canonical formations. It suggested that the excavations had been a target-oriented undertaking, well organised and thought out, a narrative that museum display has largely taken over and perpetuated until today. 


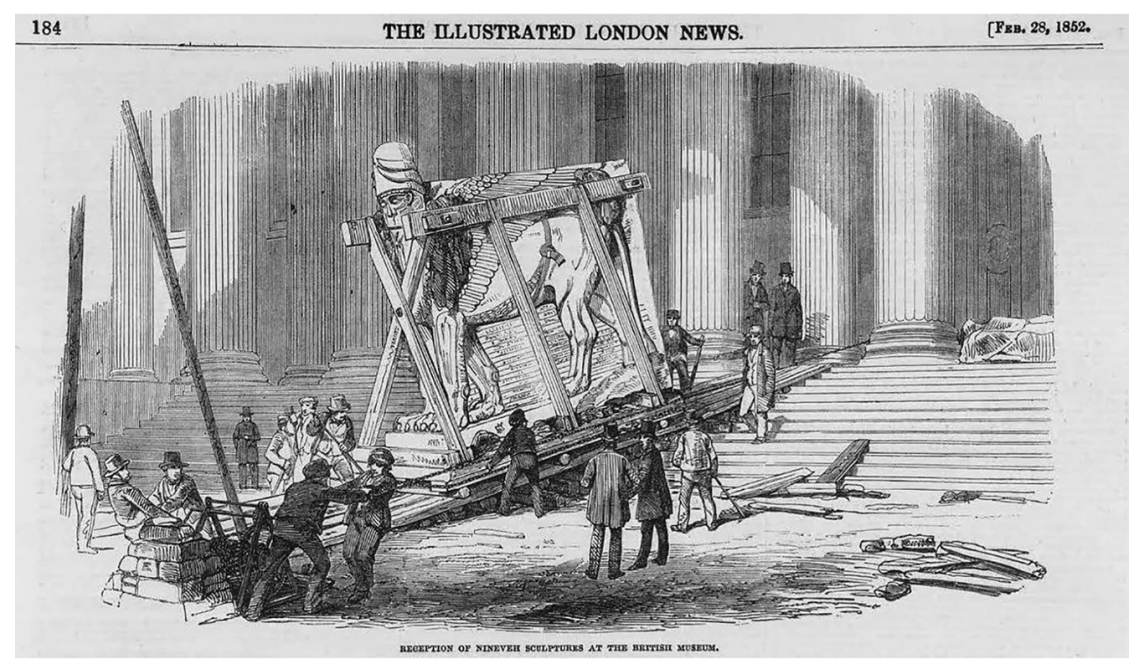

Figure 9.2 Reception of Nineveh Sculptures at the British Museum, The Illustrated London News, 28 February 1852, I 84.

A now canonical image appeared in an 1851 issue of The Illustrated London News, for example. As visual construct, another mise en scène, it retrospectively legitimised the arrival of objects from Mesopotamia that took place a few years earlier. A winded lamassus is being hauled up the entranceway of the British Museum, into a building, which had only just been completed. The statue's gaze is directed outwards, as though it were to take its last look at freedom before entering the canonical order of the museum's interior (be reminded that Rakowitz's lamassu was granted open-air enclosure where its gaze was directed towards his former home Iraq, as well as Westminster, where the UK parliament sits). Yet such images can be read along and against the grain (Stoler, 2009) by not treating them as a value-free historical record (Brusius, 2012). Like any museum display, they must be read alongside other sources and within a wider context.

Mid-nineteenth-century expeditions were not yet a means to an end for institutionalised disciplines - archaeology as a university discipline did not yet exist but subject of antiquarian investigation as part of British and French imperial 'adventures' in the eastern part of the Ottoman Empire. The published visual and textual sources - a 'display' of second order - staged these expeditions as events under control and a clear goal, not uncommon arguments in the historiography of empire. In historical research, this European self-presentation has only been challenged by few publications so far that have also created more awareness for hitherto lesser known Ottoman agency and attitudes towards the excavations (Bahrani, Celik, \& Eldem, 2011; Bilsel, 2012). These newer and more recent narratives, however, have yet to appear on labels on museum walls. Instead, the British removal of artefacts continues to be told as a heroic narrative in most museum displays that only know one side of the story. If they get mentioned or shown at all, locals are presented as passive observers or aiders. 
Accounts of the actual transport and integration of the finds also tell a different story. People like Layard relied heavily on mediators such as the Assyrian Hormuzd Rassam (Reade, 1993). Several objects went adrift in the river Tigris or during transport on their way. Those that made it arrived in Britain around 1850 after often cumbersome transport routes, heavily relying on the infrastructure of the British Empire. Artefacts, as Fred Bohrer argued (Bohrer, 2003), appeared to shift between being objects of research, trophies or curiosities. Instead of being considered enrichments of the collection, many considered them a burden. Particular names and places on the cuneiform tablets did not match the ones mentioned in the scripture, and ended up in storage because they threatened canonical biblical ideas, rather than confirming them (Brusius, 2012).

Museums rarely tell stories about objects backstage, where keepers asked themselves what in the world they were going to do with certain objects, such as the huge statues and the thousands of undeciphered cuneiform tablets. In storage, the objects sometimes lay around for years before specialists endowed them with importance (Brusius \& Singh, 2018). These kinds of stories can be unearthed once one re-reads museum archives and visual images more critically and without the 'end product' of museum display in mind. They show how the actual material legacies of the Middle East turned out to be utterly ambiguous. What can be revealed here is a narrative of museum objects that complicates the master narrative - one that is not always about European heroism, preservation, staging and display, and not even about clear starting and end points. Instead, we find stories about uneven power structures, local agency, Western neglect, and the contingency of Western collecting.

We will see, for example, that the apparent triumphalist story of arrival and appropriation of objects in European's museums and their supposed cultural 'home', is also a story about how artworks were 'lost' in space over long periods of time. This can be particularly argued for the very first expeditions in the Middle East as carried out by the British and the French (the latter under Paul-Émile Botta and then Victor Place in the 1840s and 1850s) but did not necessarily change once archaeology was institutionalised in museums and academies around 1900. When the architect and archaeologist Robert Koldewey (1855-1925) returned to Berlin with objects from his expeditions to the ancient city of Babylon in 1898, for example, it was not clear either where to 'fit' Babylon within the broader narrative. Fragments were also stuck in transit or stored in preliminary buildings on Berlin's Museum Island for decades before the Ishtar Gate and the Processional Way were finally reassembled and put on display in the 1920s (Brusius, 2017b). Many of the bricks are not displayed until even today. It is an accepted fact that large parts of the Ishtar Gate consist of reproduced tiles because they fit the reconstruction of the gate better than the original tiles. How is it justified that a large number of the fragments that had not been used are still kept in storage facilities, and for what purpose? Objects are frequently removed and collected for the sake of accumulation, to accommodate an anxiety of loss (Morgan and Macdonald, 2020). But the purpose of these objects in store is ill-defined, especially if never to be displayed, and never to be studied. This applies in particular to objects from Mesopotamia, 
culturally appropriated by European museums and yet too ambiguous to fit existing taxonomies easily. These questions gain momentum at a time when museums are under increased pressure to respond to calls for repatriation. In Babylon, various attempts were made of a reconstruction with fake tiles, while the original bricks remain safely archived in Berlin. How should we approach such realities today, as the public role and image of museum is changing, and marginalised groups demand its democratisation?

\section{Archaeologies of the community}

One could even ask whether objects are not safest when they are not excavated at all, in particular in light of destruction. Those sculptures never unearthed by nineteenth-century European archaeologists in Mesopotamia, for example, cannot be easily destroyed by natural disaster or in violent acts. Assyriologist Eleanor Robson explained how in the case of Mesopotamia, large areas of Assyrian cities have actually never been surveyed, excavated and displayed. There are millennia of archaeological deposit underneath the standing remains on the royal citadels at Nineveh, Nimrud and Assur. Dozens more winged lions still lie untouched under their earthen mounds underneath the ones that were destroyed (Robson, 2015). Experts suggest that it is the unseen objects that are the safest of all.

Robson also challenged the stark contrast drawn between heroic Victorian antiquarianism embodied by figures such as Austen Henry Layard, and the Western idea of oriental iconoclastic barbarism. This view is simplistic, she argued, and ignores Iraqi professionals who have been studying this material for decades. A small number of archaeologists now prefer to invest into projects, which serve local populations as well as scholarship and the public thirst for 'heritage'. Successful contemporary community projects, partly conducted with international collaborators, show how communities are increasingly becoming involved in 'heritage projects', such as excavation of ancient structures, informing analysis of its past and helping improve present conditions and understand sites in their regional context from a holistic approach. On the ground, however, destruction is ongoing through the dismantling of scholars and institutions in conflict zones, which often prevents local academic expertise and community infrastructure in the places where the artefacts were excavated, such as Iraq, to do their important work (Robson, 2015). In spite of these difficulties, residents have made valuable contributions to the preservation and study of their heritage; and they can surely do so in museums as well. ${ }^{5}$

Such practices acknowledge that 'archaeology', or more precisely, preservation, can thus also go beyond official forms of excavating and the subsequent safeguarding and displaying of objects in museums. In fact, what is now considered 'heritage' has often been required to reuse (and thus preserve and display) objects in new urban structures. Well-known examples include Rome's Pantheon, a Christian conversion of a Roman building (Altekamp, Marcks-Jacobs, \& Seiler, 2013). Not long ago in Europe, an ancient object dug up by civilians was not necessarily considered part of a criminal act. This shows that parameters for what the right 
'destination' for ancient objects are shifted considerably in post-war Europe. ${ }^{6}$ Recontextualisation and the vivid memory that came with objects can be considered as another form of museological memory. Only the twentieth century brought significant changes to this cultural activity when archaeology became a professionalised discipline, and looting a crime, which too must be seen in context. As William Carruthers (2015) stated: 'without understanding what it is that actually motivates people to loot artefacts, stopping the practice will be almost impossible. We also risk alienating groups of people who, ultimately, may not have much of a choice when they loot. Rampant inequality and poverty clearly play a role in their actions'. These kind of modern realities in which Western museums participate, in as much as they have long relied on the trading of antiquities, are also part of the story; as much as measures to control and prevent illicit trade have been implemented (though not always successfully).

So could reworking past material also be considered a form of display and these object biographies become a new form of knowledge? In the context of tangible heritage and its destruction, it has been argued that material sites and buildings should be considered dynamic and ongoing processes that cannot be attached to one particular moment or display in time (Holtorf, 2015). Yannis Hamilakis has shown that ancient objects were subject to a multisensory manner, including the tactile, not just vision. They were activated multiple times, and coexisted with various antiquities of different eras (Hamilakis, 2011). Objects were thus often fully embedded in the domains of contemporary life, public space, working, farming, and places of worship. Display, in other words, does not necessarily mean that objects become museological trophies (Rico, 2016). It means that stories are in themselves injected in the material, and that various knowledges can exist in parallel. When will these stories count as 'knowledge' on museum display?

\section{Conclusion}

This chapter examined how the authoritative voice of the museum mostly continues to tell the story of humanity, geographies and temporalities through its display without addressing the needs and concerns of a potentially more diverse, and not exclusively White-European, audience. Analysing current tendencies in respect to tribulations and interpretations of Middle Eastern archaeological artefacts, it pointed to the malleability, fluidity and lack of palpability of such objects. The display of these objects is an example par excellence for the articulation between scholarship, religion and science popularisation in museums in as much as it shows the limits of how value and significance is attached to objects from regions such as the 'Islamicate World'. Epistemic meaning, scholarly knowledge production and Western expertise are currently to the fore of display, but this happens at the expense of political and cultural connections, which could provide other meaningful content for audience members. Such critical interventions are often left to artists, and rarely commissioned with a permanent framework in mind. The Middle East, in most of these displays, is mainly located in the past, but rarely in the present. 
The BP protests at the British Museum, in particular those that took place around the Ashurbanipal exhibition in 2018 and 2019, can be described as a significant moment in the history of Ancient Near Eastern Art and its relation with Middle Eastern diaspora communities. For some participants, it was the first time ever in a museum, or even in their supposed home country (in this case Britain), that they felt they 'belonged':

For the majority of my life it seemed like the world had turned against my people, and didn't care that Iraqis were slaughtered, demonized, and dehumanized so long as it meant that gas prices were low and oil 'flowed' freely in the West. But on that day in the rehearsal room and later at the museum, where hundreds of allies showed up dressed in black and chanting proudly in solidarity, it felt as though times are changing and people around the world care about me, my culture, my people, and my homeland.

(Younis, 2019)

Rakowitz' display connected the material and the human, the ancient and the modern in unique ways. The situated and contextualised way in which his lamassu connected Mesopotamian antiquity and present geopolitics by publicly displaying a resignified and remade archaeological object raised questions about the present and historical role of British colonialism and the participation of the UK in the Iraq wars. How can a lamassu in a museum become both a signifier of local communities and of imperial histories in the Middle East that find their continuation today? Why is it often so difficult to create such a sense of belonging in museum displays?

In order to make the display of Middle Eastern artefacts relevant for the future and broader audiences, their display would have to, first, break with the legacies of colonial discourses. They would have to attest to the fact that these artefacts represent traces of Europe's early 'mapping' of Middle Eastern territory, with all its (destructive) consequences. Museum taxonomies are attempts at classifying objects and people, in this case dividing them into artificial categories that mostly and exclusively label them as pre- or post-Islamic. Museums, secondly, must therefore adopt a self-reflexive approach that creates distance by explaining why objects ended up in particular departments with a particular label, and also how they 'arrived' in a museum in the first place. Stories of objects in transit, and corresponding explanation on their shifting character as they circulate across natural, social and later even taxonomical worlds would help break with the existing essentialist spell of museums.

Thirdly, collections must be programmed in order to make the very basic link with people's humanity. Kassim argues that national institutions have an 'obligation to reach out to communities who are othered by exhibitions and engage with Islam as a lived and living tradition' (Kassim, 2020). Some museums have recently introduced tours by so-called 'refugee' guides to show that Middle Eastern artefacts can be approached in various ways. But will this kind of predominantly precarious work ever become one of equal knowledge-making in museums? Will visitors ever learn in these museums that refugees arrived in Europe, because countries like Britain once invaded the countries they once called their home, building on long imperial 
projects of expansion of which archaeology was an integral part? Will we ever learn that many of the objects the destruction of which they mourn in their display were destroyed as a result of these invasions? The silence surrounding these questions goes to the very heart of the museological preservation paradigm. 'Mises en scène', or displays, are almost always acts of a political nature. At a time of immigration from the Middle East to Europe caused by violence and conflict, the display of Middle Eastern artefacts requires a new historical context. This will then allow visitors to make personal connections, unlimited by class, education, gender, race and religion.

Museums will have to decide if they want to remain depositories of artefacts that make reference to selected layers of the ancient past and triumphalist accounts of imperial histories, or instead turn towards personal and individual engagements as well as the uncomfortable aspects of Europe's past.There is more and more demand that such objects become placeholders for something other than symbols of the 'cradle of civilisation', mostly integrated into displays that 'celebrate white, middle class male intellectuals', as Paul Collins, a curator at the Ashmolean Museum, who is willing to change these structures put it recently (Collins, forthcoming). ${ }^{7}$

As museums are undergoing 'crises', this raises larger, more fundamental questions about their future functions, which the International Council of Museums suggested should also involve 'social justice, global equality and planetary wellbeing' (Small, 2019). In the current politically transformative era, analysing questions of display from all sides is a condition for creating a more humane model for the display of artefacts. Such an approach would leave behind the linear idea, which assumes museums are natural end points for the objects it holds. Recognising cultural diversity can then lead to a different engagement with museum displays, acknowledging that local stakeholders have had and still have different relationships with their various constituent pasts. These questions concern the very epistemic concepts that currently surround knowledge-making about objects in museums.

\section{Acknowledgements}

I would like to thank the editors of this volume, Charlotte Bigg, Andrée Bergeron and Jaume Sastre. I am grateful for the inspiring conversations I had during my time as a visiting researcher at CARMAH, funded by the Alexander von Humboldt Foundation as part of Sharon Macdonald's Alexander von Humboldt Professorship.

\section{Notes}

1 The plinth was designed by Sir Charles Barry in 1841 and intended for a figure on horseback to join George IV in Trafalgar Square's north east corner. British military stalwarts Sir Charles Napier and Henry Havelock occupy the others.

2 For the UK (London and Oxford), see in particular Chapter 2 and 5; for Paris Chapter 4; and for Berlin Chapter 6. See also the Samarra project: https://www.museumsfernsehen.de/museum-fuer-islamische-kunst-kurzfilme-ueber-samarra/

3 Both aspects relate to one another due to his grandfather's import-export business (dates were one of Iraq's most important exports before the trade was damaged by two successive Gulf Wars). 
4 Various photographs of Palmyra and Tadmour, Syria, taken by the American Colony, 1920 (approximately to 1933) are held in the Library of Congress, Photo Department,LC-M32.

5 For some recent project examples, see http://www.ummeljimal.org/ and http:// www.ucl.ac.uk/nahrein

6 In Italy, for example, unearthing ancient objects was a widespread activity for centuries (Rose-Greenland, 2014). Artefacts were removed from the soil and re-incorporated into the social realm as votives and treasure. Women and men knowledgeable about ancient objects and sites were considered respected human repositories of history.

7 Personal communication with Paul Collins (Jaleh Hearn Curator of Ancient Near East in the Department of Antiquities at the Ashmolean Museum).

\section{References}

Abu El-Haj, N. (2001). Facts on the ground:Archaeological practice and territorial self-fashioning in Israeli society. Chicago, IL; London: The University of Chicago Press.

Al-Khalili, J. (2010). Pathfinders: The golden age of Arabic science. London: Allen Lane.

Altekamp, S., Marcks-Jacobs, C., \& Seiler, P. (Eds.). (2013). Perspektiven der Spolienforschung, 1: Spoliierung und Transposition. Berlin: De Gruyter.

Armitstead, C. (2018, 26 March). Fourth plinth: How a winged bull made of date syrup cans is defying Isis. The Guardian. Retrieved from https://www.theguardian.com/artanddesign/ 2018/mar/26/michael-rakowitz-invisible-enemy-should-not-exist-fourth-plinth-wingedbull-date-syrup-cans-defying-isis

Bahrani, Z. (1998). Conjuring Mesopotamia. Imaginative geography and a world past. In L. Meskell (Ed.), Archaeology under fire. nationalism, politics and heritage in the Eastern Mediterranean and Middle East (pp. 159-174). London \& New York: Routledge.

Bahrani, Z., Celik, Z., \& Eldem, E. (2011). Scramble for the past: A story of archaeology in the Ottoman Empire, 1753-1914. Istanbul: SALT.

Bernbeck, R. (2013). Heritage void and the void as heritage. Journal of the World Archaeological Congress, 9(3), 526-545.

Bilsel, S. M. C. (2012). Antiquity on display: Regimes of the authentic in Berlin's Pergamon Museum. Oxford \& New York: Oxford University Press.

Bohrer, F. (2003). Orientalism and visual culture: Imagining Mesopotamia in nineteenth-century Europe. Cambridge \& New York: Cambridge University Press.

Bohrer, F. (2015, 14 May). The destruction of art and antiquities in our time. Los Angeles Review of Books. Retrieved from https://lareviewofbooks.org/article/the-destruction-ofart-and-antiquities-in-our-time/

Brown, M. (2016, 19 April). Palmyra's arch of triumph recreated in Trafalgar Square. The Guardian. Retrieved from https://www.theguardian.com/culture/2016/apr/19/palmyrastriumphal-arch-recreated-in-trafalgar-square

Brusius, M. (2012). Misfit objects. Excavations in Mesopotamia and biblical imagination in mid-19th century Britain. Journal of Literature and Science, 5(1), 38-52.

Brusius, M. (2016, 25 April). The Middle East heritage debate is becoming worryingly colonial. The Conversation. Retrieved from https://theconversation.com/the-middle-eastheritage-debate-is-becoming-worryingly-colonial-57679

Brusius, M. (2017a, September 26). Das Humboldtforum ist nur der Anfang. Imperialistische Zerstörung und museale Konservierung waren schon immer Komplizen. Doch wie viel kritische Sammlungsgeschichte ertragen Museen, ohne sich abzuschaffen? Frankfurter Allgemeine Zeitung, 226.

Brusius, M. (2017b). The field in the museum. Puzzling out Babylon in Berlin. Osiris, 32, 264-285. 
Brusius, M. (2019). Objects and History adrift. Contextualizing the debate about Middle Eastern 'heritage'. In U. Fleckner \& E. Tolstichin (Ed.), Das verirrte Kunstwerk. Bedeutung, Funktion und Manipulation von 'Bilderfahrzengen' in der Diaspora (pp. 55-71). Berlin \& München: De Gruyter.

Brusius, M., \& Singh, K. (2018). Introduction. In K. Singh \& M. Brusius (Eds.), Museum storage and meaning. Tales from the crypt. (pp. 1-34). London: Routledge.

Carruthers, W. (2015, 29 January). What we are talking about when we talk about Tutankhamun's Beard. Max Weber Programme Blog. Retrieved from https://blogs.eui.eu/ maxweberprogramme/what-we-are-talking-about-when-we-talk-about-tutankhamunsbeard/

Collins, P. (forthcoming). Telling stories at the Ashmolean Museum: An Ancient Near East Gallery for the 21st Century? In A. Stevenson (Ed.), The Oxford Handbook of Museum Archaeology.

Cunliffe, E. (2016, 31 March). Should we 3D print a new Palmyra? The Conversation. Retrieved from https://theconversation.com/should-we-3d-print-a-new-palmyra-57014

Cuno, J. (2020, 6 January). Getty stands against threats to cultural heritage. The Iris. Behind the Scence at the Getty.https://blogs.getty.edu/iris/getty-stands-against-threats-to-culturalheritage/

Díaz-Andreu, M. (2007). A world history of nineteenth-century archaeology. Nationalism, colonialism, and the past. Oxford: Oxford University Press.

Emberling, G., \& Petit, L. P. (Eds.) (2019). Museums and the Ancient Middle East: Curatorial practice and audiences. London: Routledge.

Galor, K. (2017). Finding Jerusalem: Archaeology between science and ideology. Oakland, CA: University of California Press.

Gansell,A. R., \& Shafer, A. (2019). Testing the canon of ancient Near Eastern art and archaeology. Oxford \& New York: Oxford University Press.

Hamilakis,Y. (2011). Indigenous archaeologies in Ottoman Greece. In Z. Bahrani, Z. Celik, \& E. Eldem (Eds.), Scramble for the past: A story of archaeology in the Ottoman Empire 17531914 (pp. 49-69). Istanbul: SALT.

Harrow, L., \& Wilson, P. L. (1976). Science and technology in Islam:An exhibition at the Science Museum, London, 7 April-29 August 1976. London: Crescent Moon Press [for the World of Islam Festival].

Holtorf, C. (2015). Averting loss aversion in cultural heritage. International Journal of Heritage Studies, 21, 405-442.

Kassim, S. (2020, 7 February). There is no mutual fascination: Why the British Museum's 'inspired by the East' is not inspired (at least, not to me, a heartbroken Muslim Middle Easterner). Lucy Writers' Platform. Retrieved from https://lucywritersplatform. com/2020/02/07/there-is-no-mutual-fascination-why-the-british-museums-inspired-bythe-east-is-not-inspired-at-least-not-to-me-a-heartbroken-muslim-middle-easterner/

Kennedy, M. (2018, 28 March). Winged bull made of syrup cans unveiled on fourth plinth. The Guardian. Retrieved from https://www.theguardian.com/artanddesign/2018/mar/ 28/winged-bull-syrup-cans-unveiled-fourth-plinth-trafalgar-square\#: :text=A\%20 re\%2Dcreation $\% 20$ of $\% 20$ a, $10 \% 2$ C500\%20mpty $\% 20$ date $\% 20$ syrup $\% 20$ cans.

Luke, B. (2018, 28 March). London's Fourth Plinth unveiled: Michael Rakowitz's winged bull sculpture made from date syrup cans. The Art Newspaper. Retrieved from https:// www.theartnewspaper.com/news/michael-rakowitz-s-winged-bull-made-fromdate-syrup-cans-unveiled-in-london-s-trafalgar-square

McEwan, O. (2018, April 5). Michael Rakowitz recreates a sculpture destroyed by ISIS for London's Trafalgar Square. Hyperallergic. Retrieved from https://hyperallergic. com/436134/michael-rakowitz-fourth-plinth-trafalgar-square-london/ 
Meskell, L. (Ed.). (1998). Archaeology under fire: Nationalism, politics and heritage in the Eastern Mediterranean and Middle East. London: Routledge.

Morgan, J., \& Macdonald, S. (2020). De-growing museum collections for new heritage futures. International Journal of Heritage Studies, 26(1), 56-70.

Oliver, M. (2016,19 April). Oxford experts recreate ancient Syrian monument in Trafalgar Square after original destroyed by Islamic State. Oxford Mail. Retrieved from https:// www.oxfordmail.co.uk/news/14437254.oxford-experts-recreate-ancient-syrian-monumenttrafalgar-square-original-destroyed-islamic-state/.

Pollock, S., \& Bernbeck, R. (Eds.). (2005). Archaeologies of the Middle East: Critical perspectives. Oxford: Blackwell Pub.

Quirke, S. (2010). Hidden hands: Egyptian workforces in Petrie excavation archives, 1880-1924. London: Duckworth.

Reade, J. (1993). Hormuzd Rassam and his discoveries. Iraq, 55, 39-62.

Rico, T. (2016). Constructing destruction: Heritage narratives in the tsunami city. London: Routledge.

Riggs, C. (2011, 24 February).We've been here before. Times Higher Education. Retrieved from https://www.timeshighereducation.com/cn/news/weve-been-here-before/41 5262.article

Robson, E. (2008). Mathematics in Ancient Iraq: A social history. Princeton, NJ: Princeton University Press.

Robson, E. (2015, 25 March). Modern war, ancient casualties. The Times Literary Supplement.

Robson, E. (2019). Ancient knowledge networks: A social geography of cuneiform scholarship in firstmillennium Assyria and Babylonia. London: UCL Press.

Rose-Greenland, F. (2014). Looters, collectors and a passion for antiquities at the margins of Italian society. Journal of Modern Italian Studies, 19.

Searle,A. (2018, 28 March). Fourth plinth review - 'My heart is in my mouth'. The Guardian. Retrieved from https://www.theguardian.com/artanddesign/2018/mar/28/fourth-plinthreview-my-heart-is-in-my-mouth

Shalem, A. (2012). Dangerous claims: On the 'othering' of Islamic art history and how it operates within global art history. Kritische Berichte. Zeitschrift für Kunst- und Kulturwissenschaften, 2, 69-86.

Shamouel, E. R. [@EvaShamouel]. (30.3.2018). [Twitter].

Shaw, W. (2018). Preserving preservation. Maintaining meaning in museum storage. In K. Singh \& M. Brusius (Eds.), Tales from the crypt: Museum storage and meaning (pp. 152-168). Abingdon, New York: Routledge.

Shaw, W. M. K. (2019). What is 'Islamic' art?: Between religion and perception. Cambridge: Cambridge University Press.

Sherman, D. J. (Ed.) (2008). Museums and difference. Bloomington, IN: Indiana University Press.

Small, Z. (2019, 19 August). A new definition of 'museum' sparks international debate. Hyperallergic. Retrieved from https://hyperallergic.com/513858/icom-museum-definition/

Stoler, A. L. (2009). Along the archival Grain: Epistemic anxieties and colonial common Sense. Princeton, NJ \& Oxford: Princeton University Press.

Tharoor K., \& Maruf M. (2016, 1 March). Museum of lost objects: The Temple of Bel. BBC News Magazine.

Trump, D. [@realDonaldTrump]. (04.01.2020). [Twitter].

Younis, Y. (2019, 19 February). Why I protested a British Museum exhibition of my own people's history. New Internationalist. Retrieved from https://newint.org/features/2019/ 02/19/protesting-british-museum-ashurbanipal-exhibition 